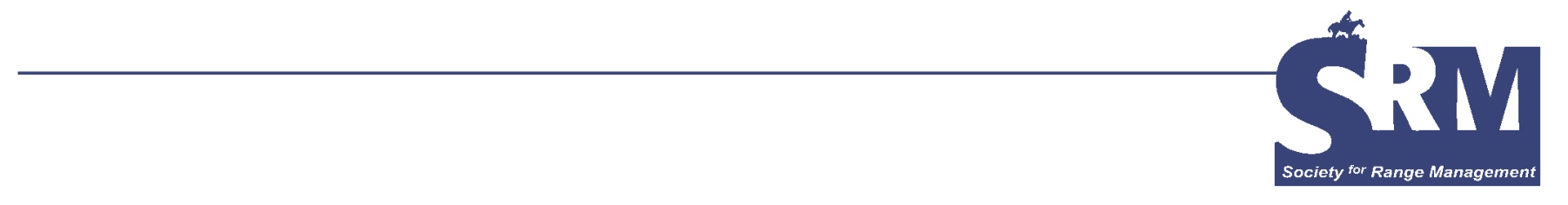

\title{
Thirteenth in a Series: Insight From SRM's Charter Members
}

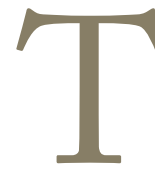

he SRM History Committee has conducted interviews with many of the Society's Charter Members to capture their perspective of events leading to and subsequent to the formation of the American Society of Range Management in 1947-1948. Interviews from several of these individuals will be shared for today's SRM members to enjoy and learn from.

\section{SRM Charter Member - W. E. Howard \\ Editor's Note: Dr. Walter E. (Howdy) Howard, long-time University of California, Davis, faculty member, sent his written statement for the record. Howdy's home address is 24 College Park, Davis, CA 95616 (wehoward@ucdavis.edu, tel: 530-756- 1509). His office address is Wildlife, Fish and Conservation Biology, University of California, Davis, CA 95616 (tel: 530- 752-2564), where he still spends each morning.}

My name is Walter E. (Howdy) Howard. I was born April 9, 1917. My field of interest has always been to find better ecological ways people and wildlife can cohabit with human-wildlife conflicts. I no longer do research but write books. Last year it was Saved by Bed Bugs, a frank autobiography with 278 colored pictures. In January 2006, Nature Needs Us will come out. It is an in-depth analysis of the reasons why nature needs our help in human-altered environments. I am currently editing a second edition of Nature Needs $U s$, even though the first copy will not be out until January 2006. I am also writing about my World War II experiences as a ski trooper invading Kiska Island.

I received my $\mathrm{AB}$ (1939) from the University of California at Berkeley and both my MS (1942) and PhD (1947) from the University of Michigan. When I joined the faculty of UC Davis in 1947 it was called the Division of Agricultural Zoology at the University Farm. I was hired to research rodent and other wildlife problems of rangelands.
For the first 2 years I was stationed at the US Forest Service, Forest and Range Experiment Station, San Joaquin Experimental Range (SJER) at O'Neals, California. My initial research projects were studying the life history and biology of pocket gophers and, with Ken Wagnon and Jay Bentley, the degree to which ground squirrels competed with heifers for spring forage.

Being stationed at the SJER in 1947, I enthusiastically joined Harold Biswell, Jay Bentley, M. W. Talbot, and others as a charter member of the Range Management Society.

With cooperation from R. L. Fenner and graduate student Hank Childs, we made a very significant discovery at SJER concerning wildlife survival of range fires. We showed that most mammals and other animals had evolved a way of surviving fires, and that the main mortality factor was from loss of oxygen, not heat. We demonstrated that if a mammal, located on the ground surface, was covered so as to protect it from heat, that even though fire had eliminated the oxygen, the animal could obtain all the oxygen it needed from the soil. This led to firefighters carrying a tarp so they could survive the lack of oxygen when a firestorm passed over them.

I participated at the beginning of brush burning activities, when the goal was to convert millions of acres of California chaparral into grasslands. An early plan was to broadcast the seeds as soon as possible in order to use the ash as a seedbed. In cooperation with Milt Miller we showed how the ash blew away and that the fire did not kill the harvester ants and rodents, which would then eat the seeds. For a while we dyed the seeds yellow to protect them from birds and treated the seeds with a rodenticide to protect them from ants and rodents. However, it was soon realized that the best solution was to drill the seeds.

Another finding with brush burning was that wildlife had a high ability to survive fires. They have evolved the neces- 
sary escape routes, especially by entering open burrows. We found that it is actually unusual for a deer, rabbit, or bird to be killed by either a controlled fire or wildfire.

In cooperation with Ken Wagnon and Jay Bentley at SJER we measured the degree to which ground squirrels competed with heifers for spring forage, and hence the need for squirrel control. After developing a live trap for pocket gophers, with assistance from graduate students, I made the first life-history investigation of pocket gophers. This was at the SJER. This study led to the development of the original burrow builder for controlling pocket gophers. Robert Kepner at UC Davis designed it. I took this design to Denver, Colorado, and gave it to the US Department of Interior's Animal Damage Control group, which then was in the US Fish and Wildlife Service, so they could build one to test in their area.

My memory of the first ASRM Meeting in Salt Lake City is that I had to take an overnight train to get there. Since the glands in both of my armpits were swollen, my doctor gave me a note of instructions for the train conductor that I was to hang around my neck in case I came down with plague. I had been handling California ground squirrels, which can carry plague. Fortunately, I survived.

I used the membership list and first meeting of the California Section of SRM to form the California Section of The Wildlife Society.

Rangelands offer an exciting and rewarding field for researchers. I sure miss my personal involvement in rangeland research and strongly urge young people to participate in rangeland activities.

SRM Charter Member - Dr. Roald A. Peterson Editor's Note: Dr. Roald A. Peterson, 90, of Fayetteville, Arkansas, passed away Friday, January 9, 2004, in Fayetteville, of pneumonia. He was born March 31, 1913, in Watford City, North Dakota, to Sigvart and Elena (Carlsen) Peterson. The following obituary was printed in the Northwest Arkansas Times.

Roald A. Peterson was the ninth of 11 children, 2 born to his parents in Norway before they immigrated and homesteaded on a large farm in North Dakota. Both his Norwegian heritage and being raised on a cattle farm had a profound influence on him. He was 2 months and 22 days away from his 91 st birthday.

Dr Peterson was an Adjunct Professor of Agronomy at the University of Arkansas, a member of the Society for Range Management, Sigma XI, The Scientific Research Society, the Unitarian Universalist Fellowship in Fayetteville, and Partners for the Americas.

He received both his Bachelors and Masters degrees in botany from the University of North Dakota, Fargo, North Dakota, and his $\mathrm{PhD}$ in plant ecology from the University of Minnesota, Minneapolis, Minnesota.

He is survived by 2 daughters, Hannah S. Waite, son-inlaw Dr Thomas W. Waite of Chaska, Minnesota, and Rima S. Peterson of Fayetteville, Arkansas; two sisters, Ruby
Howard of Cottonwood, Arizona, and Alice Hawley of Kemah, Texas; one granddaughter, Sarah Morse of Chaska, Minnesota; and many nephews and nieces throughout the United States, Puerto Rico, Germany and Spain as well as extended family members in Norway. He was preceded in death by his beloved wife of over 40 years, Carmen, daughter Andrea and son Malcolm.

During his extensive and rich career, after the United States had entered the war, he served training World War II pilots in ground flight instruction and meteorology at the then-Army Air Force base near Fort Worth, Texas.

In the 1930s and early 1940s, he was an early pioneer in integrating cooperative work, empowering both poor blacks and whites who worked lands they did not own throughout the South, as well as encouraging and helping farmers in the North to form cooperatives that gave them both economic and political power and clout unheard of until those days.

He worked for the US Department of Agriculture in both range management and forestry, primarily in Montana.

A little known aspect of his wonderful but often difficult life, was that after nearly a decade of being hounded by the House Un-American Activities Committee, and cleared before every tribunal he was brought before, he was ultimately blacklisted by the infamous Joe McCarthy, Roy Cohn and J. Edgar Hoover group of legal thugs on the word of one man, the only person, among many who testified in Washington on his behalf, friends and colleagues who knew him as an extraordinary human being, were intimately familiar with his often ground-breaking and vital work, not to testify in his favor. To his great credit, he never held it against this individual, understanding that intimidation and fear ruled the testimony of so many during those dark days of our history.

Though this ended his work in the United States, after attaining so much international acknowledgment and recognition of his outstanding work on almost every continent of the planet, J. Edgar Hoover was forced by then-President John F. Kennedy to write him a letter of apology and an invitation to return to work in the United States. He did not do so until his retirement in 1979.

The blacklisting turned out to be a blessing in disguise, as he and his family left the country and in 1953 he was appointed Director of Agriculture of the Southern Zone of the Organization of American States in South America. His area of work comprised the countries of Uruguay, where he lived and OAS headquarters were located, Argentina, Brazil, Paraguay and Chile.

It was here that he met, fell in love with and in 1956 married the Puerto Rican beauty, Carmen S. Sanchez, who held the same directorship in the same countries, in what was then known as home economics.

He had been a single father, with a nanny, for 6 years, to his 3 children, since the loss of his first wife, Lillian Alexander, during the devastation caused by the fallout of the HUAC investigations. 
Dr. Peterson's career in South America was filled with joys, travels and work: with men and women of each country, training them in the science and practical applications of agronomy, range management, animal husbandry, land care, etc., to maximize good land use, better yields, nutrition, healthy cattle and food production. Both he and Carmen received many awards of recognition for their contributions from Heads of State, Secretaries of the Interior, Ministries of Agriculture, as well as national and international organizations too numerous to mention.

After a work trip and international congress in Australia and New Zealand, Dr Peterson was nominated to head a division of the Food and Agricultural Organization of the United Nations, headquartered in Rome, Italy. He accepted the position and the family moved to Rome in 1961, from where he worked and traveled until his last appointment in the Dominican Republic.

It was shortly after this nomination to serve in the FAO that he was invited by Queen Elizabeth and Prince Phillip to receive honors, as well as by the King and Queen of Norway, when he and Carmen took advantage of being there, to look to and visit the extended family, including siblings of parents, whom he got to talk to by telephone and thus to reestablish connections that had been long lost.

During those years, he did what was probably the most impacting and extensive work of his life.

He was the first foreigner to be invited, by the thenSoviet government, to come to the USSR and go to Outer Mongolia, working and living with tribal people there, on the problem of milk conservation and preservation. Even on his deathbed he commented how he had learned so much in Mongolia, not only from the people, but about them, by watching their horses. It was one of the highlights of his many work-related travels, which he spoke frequently about, and which, as an avid horseman, had especially enjoyed their small, but very fast, adept horses.

His work with FAO took him to every country in Africa, where he trained and worked with teams, which hopefully today are still able to carry on his legacy. He lived in the bush country, with Pygmy, Zulu and many other tribal peoples and thoroughly enjoyed it, enriching our lives with stories, photographs and artifacts particular to each tribe, still dear to him after all these years.

He traveled and lived and worked with nomadic tribes as well as government officials and his teams, in what was then Persia, in Egypt, Lebanon, Israel, Morocco and all over India, always bringing home stories and artifacts handmade in those regions, igniting his family's interest and curiosity to visit and travel to them themselves.

Dr Peterson retired in 1979 and moved with his family to Fayetteville, Arkansas. He chose Northwest Arkansas as his final home for its peacefulness, scenic beauty and opportunities to do agricultural research through the University of Arkansas. Due to his experience and continued contributions to the field, he was named an Adjunct Professor of Agronomy. He was one of the Arkansas-East Bolivia Partners of the Americas, and did short-term consultations in both Bolivia and Sierra Leone. He was also a dedicated member of the Unitarian Universalist Fellowship of Fayetteville, where he served as president for several years.

The epitome of the green thumb, he was a passionate gardener of both vegetables and flowers throughout his life. He was well known for his bountiful tomato crops. During his retirement he grew and did research on several lesserknown legumes and vegetables, including the pigeon pea, chayote, kohlrabi, and the Jerusalem artichoke. Always an avid reader, he enthusiastically participated in the Great ideas and Soul Searchers discussion group at Butterfield Trail Village.

Tom Bedell is a member and former chairman of the SRM History Committee and a member of the Pacific Northwest Section living in Philomath, Oregon, tbedell@peak.org. 